\title{
Integrative Gene Expression Profiling Reveals That Dysregulated Triple microRNAs Confer Paclitaxel Resistance in Non-Small Cell Lung Cancer via Cotargeting MAPT [Corrigendum]
}

Cai Y, Jia R, Xiong H, et al. Cancer Manag Res. 2019;11:7391-7404.

The authors have advised due to an error at the time of figure assembly, Figure 1D on page 7393 is incorrect. The correct Figure 1 is shown below.

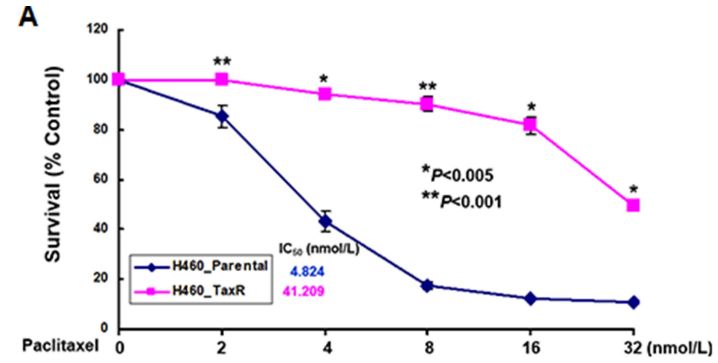

B
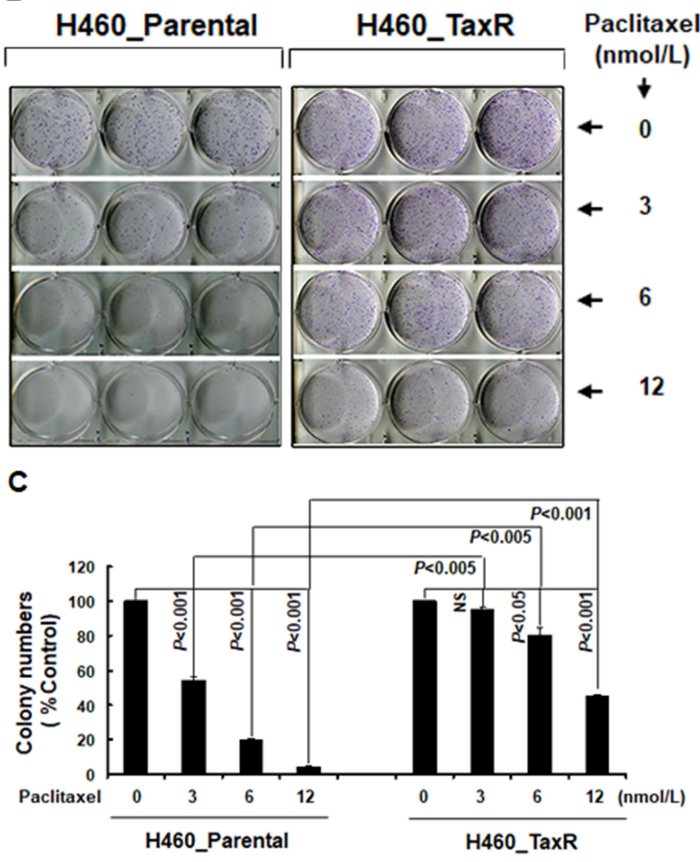

The authors apologize for this error and advise it does not affect the results of the paper.
D
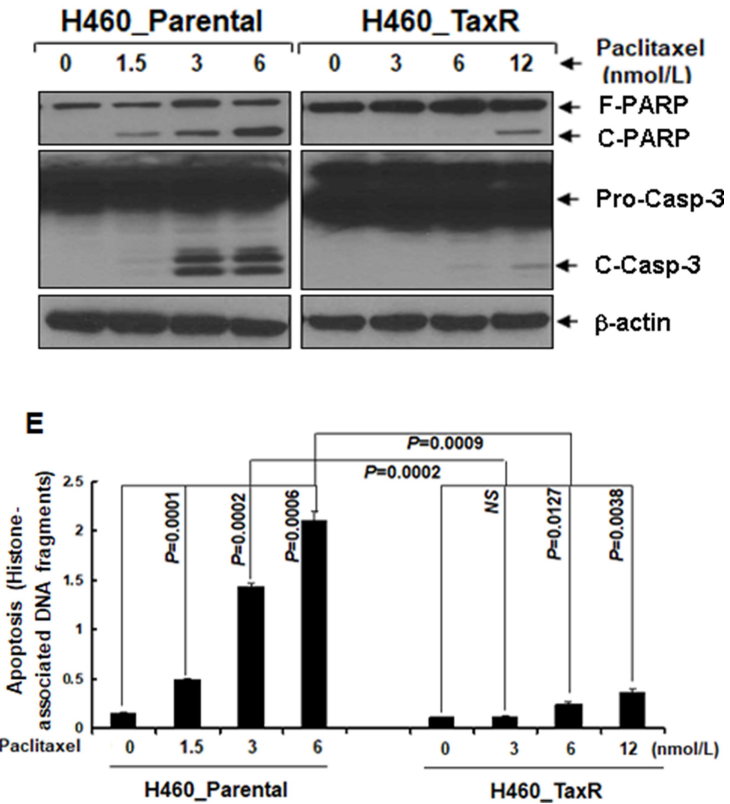

Figure I Identification of paclitaxel-resistant NSCLC cells.

Notes: (A) Human NSCLC cells (H460_Parental and H460_TaxR) treated with indicated concentrations of paclitaxel for $72 \mathrm{~h}$ were subjected to cell viability assay. (B, C) H460 Parental and H460 TaxR cells were grown in triplicates in the absence or presence of indicated concentrations of paclitaxel for 2-3 weeks. The pictures and numbers of the cell colonies were obtained by the QuantiOne software of Fluor-S ${ }^{T M}$ Multimager. (D, E) H460_Parental and H460_TaxR cells were treated with indicated concentrations of paclitaxel for $24 \mathrm{hrs}$. Cells were collected and subjected to Western blot analyses of PARP, Casp-3 or $\beta$-actin (D), or apoptotic-ELISA (E). Abbreviations: F-PARP, full length of poly(ADP-ribose) polymerase; C-PARP, cleaved PARP; Pro-Casp-3, Caspase-3; C-Casp-3, cleaved caspase-3; ELISA, enzymelinked immunosorbent assay. 


\section{Publish your work in this journal}

Cancer Management and Research is an international, peer-reviewed open access journal focusing on cancer research and the optimal use of preventative and integrated treatment interventions to achieve improved outcomes, enhanced survival and quality of life for the cancer patient.

The manuscript management system is completely online and includes a very quick and fair peer-review system, which is all easy to use. Visit http://www.dovepress.com/testimonials.php to read real quotes from published authors.

Submit your manuscript here: https://www.dovepress.com/cancer-management-and-research-journa 